\title{
Evaluation of Implementation of Inclusive Education at Primary School
}

\author{
$1^{\text {st }}$ Rokhmaniyah \\ Primary Teacher Education \\ Sebelas Maret University \\ Surakarta, Indonesia \\ rokhmaniyah@staff.uns.ac.id
}

\author{
$2^{\text {nd }}$ Chamdani \\ Primary Teacher Education \\ Sebelas Maret University \\ Surakarta, Indonesia \\ muhamad_chamdani@staff.uns.ac.id
}

\begin{abstract}
The purposes of this study are to identify and describe the strengths and weaknesses of institutions as providers of inclusive education with using the instruments that have been prepared. Evaluations are conducted to identify and explain both the opportunity and challenge of an institution that is able to be used for the institutional development in the implementation of inclusive education. The evaluation of the inclusive education at primary schools is intended as a process of identifying the indicator of the implementation of the inclusive education and finds out an event what is being done, what was done, and what is not done yet in implementing the inclusive education program at primary schools. This research uses a descriptive method with a quantitative approach. The sampling technique is used by surveying 5 primary schools with a sample of 30 teachers who taught children with special needs. The Evaluation data includes the data of general school, school-specific data and data on the implementation of inclusive schools. The data are collected using the ideal instrument index. The result of the general school is $\mathbf{1 1 . 6}$ with the ideal standard score of 19 . The specific data of the inclusive school amounts to $\mathbf{1 0 4 . 2}$ with the ideal score of 138 . While for the implementation of inclusive education data amounts to 159.1 with a total score of 381 . The Conclusions of this study are the evaluation of the implementation of inclusive education at the primary school in Kebumen regency showed the mean is $60 \%$ in the medium category. This result implies that the implementation of inclusive schools in the regency of Kebumen needs to be optimized in terms of institution, curriculum, learning, appraisal, student affairs, human resources, facilities and infrastructure, finance and society participation.
\end{abstract} school

Keywords-evaluation, inclusive education, primary

\section{INTRODUCTION}

Inclusive school is one form of equity and education without discrimination in which both children in general and children with special needs obtain the same education. In inclusion education, children with special needs do not receive special treatment or privileges, but they have an equality of rights and obligations as like other students. The cooperation of various parties such as the government, the school, and the society is very influential in the implementation because the inclusive school constitutes a new challenge for the school and society. With the implementation of the inclusive school, it is expected to create the next generation to understand and accept all forms of differences and does not create discrimination in public in the future life.

Education is one of the public sectors toward the central government and local government, so that with inclusive education is expected to solve the problems in educating children with special needs for achieving educational services without discrimination and maximizing the chance of a child to engage normal activity (Sulistyadi, 2014: 3). By inclusive education, children with special needs study together with other students to optimize their potential. It is a fact that children in general and children with special needs cannot be separated into two different communities where the child live. Therefore, the character of inclusive education should be imparted to the children with special needs, so that it is able to deal with real life in the future life. One way to do it is to modify the school curriculum and learning materials that are being taught (Erawati, Sudjarwo, \&Sinaga, 2016: 21-22).

Choiri \& Joseph (2009: 7) states, "Children with special needs are children whose education requires a specific service, as opposed to children in general". The category of children with special needs according to the National Education Law No. 20 of 2003 Article 32, paragraph 1, namely: a. blind; b. deaf; c. mentally disabled; d. quadriplegic; e. Dysruptive and HIVAIDS and drugs; f. autism; g. difficult to study/slow learner; h. gifted, talented, and indigo.

The implementation of inclusion for primary school in Kebumen was conducted from 2009. It is necessary to evaluate how far the implementation of inclusion has done in every challenge in order to obtain the effectiveness of inclusive school against discriminatory attitudes. By creating a society who wants to welcome children with special needs, 
children with special needs can obtain the same treatment as a normal child. Thus, the implementation of inclusive schools in Kebumen needs to be implemented. The implementation of inclusive education is a form of government effort. It is expected that is able to create future generations who can understand and accept all kinds of differences and do not create any discrimination in the life of the society. Some cities in Indonesia have implemented the inclusive school through cooperating between schools and municipalities. But in fact, it is still difficult to realize that an inclusive school can fulfil the needs of children with special needs. One of the difficulties is that there are still many who are not received the student with special needs students in regular schools. Therefore, a disharmony may happen in some schools that support the full implementation of the inclusive school. Each people wants to work together in realizing inclusive education in Indonesia. Thus, it rises the idea of education without discrimination. The inclusive education is still need to be concerned so that the children with special needs really get their education service in accordance with their conditions. By doing so, we can maximally respect the reality of diversity in the life of society.

\section{METHODS}

The research was conducted in Kebumen. The target population in this study is the inclusion of primary school education providers in Kebumen. The type of research is a descriptive method with a quantitative approach. The form of the data is a quantitative data. The subjects in this research are the persons or things as the source of research. The subjects are principals, teachers, and students with special needs. The data collection methods used in the implementation of this research are the principal method, namely: (1) a direct questionnaire to principals and teachers (2) a direct observation with the technique of participants (3) interviews with principals, teachers, and students. The results of the data are collected and analyzed by using the ideal instrument index.

\section{RESULT AND DISCUSSION}

Education is a basic need of every human being to guarantee the survival of human life to be more dignified. Therefore, the state has an obligation to provide services in case of the quality of education for every citizen, without exception, including those with special needs as are written in the 1945 Constitution, Article 31 (1). Unfortunately, the education system in Indonesia does not accommodate diversity, so it leads to the emergence of the segmentation of educational institutions based on religion, ethnicity, and even different physical and mental abilities. The segmentation of educational institutions has hampered the students to learn and respect the reality of diversity in society. The government of Indonesia has sought to implement inclusive education through various programs and activities with the Ministry of National Education and Culture in the province and the city/county. In practice, the implementation of inclusive education meets various obstacles and challenges. Some constraints are frequently reported such as misconceptions about the concept of inclusive education, regulations or policies that are not consistent, flexible education system and so on.

Inclusive education is one of the government policies in education for every citizen in order to obtain the distribution of education. Hence, both children with special needs and children in general can go to school and obtain the equal education and the better quality of life.

The development of education of children with special needs has undergone many changes. At first, the education of children with special needs is segregated or separated from society in general. The implementation of education such as the SLB school, there are specialties of children with special needs in accordance with their disabilities or retardation, for instance: SLB-A to school blind children, SLB-B for school children with hearing impairment, SLB-C for school children with intellectual challenges, SLB-D for school children with physical disabilities. In addition, the integrative education, or known as an integrated approach integrates the children with special needs go to regular schools.

The Implementation of the inclusive school system is one of the requirements that must be built for a society of inclusion. A society who has a mutual-respect feeling, uphold the values of diversity as the reality of life. Many cases arising in respect of the implementation of inclusive education, such as the lack of supporting inclusive education system, limited knowledge and skills of the inclusive school teachers. Therefore, the mentioned lacks show that the inclusive education system is not well-prepared.

Implementation of inclusive schools for children with special needs should create a learning-friendly environment, which allows all students can learn with a comfortable and enjoyable moment.

Implementation of inclusive schools is not as simple as organizing schools in general. The fact is that a few of children with special needs are unable to follow the policy, as in the case of receiving any information, they have the level of intelligence in below average. Besides, there is no determination of the limit number of the student acceptence, and no special infrastructure. With the support of the parents from both children with special needs and children in general, it will raise the moral support from the society. And, it might trigger the other people to help the children with special needs in the form of material support or direct interaction. Moreover, the support from both central and local governments is still limited to be distributed in across all regions. 
1. Policies and support of the school administration to the implementation of inclusive education system

Based on the results of the data analysis are showed that almost all schools which organize inclusive education in primary schools Kebumen district have implemented the policy of inclusive education. It can be seen from almost any school that organizes inclusive education in elementary Kebumen, has the vision and mission of inclusive education. Nearly all schools can show the specific ways that are school administrators and teachers understand the concept of inclusive education. And also, nearly all schools give freedom to the teachers to use creative teaching methods in helping children to learn. It is seen that the 3 aspects of school policy in supporting the implementation of inclusive education in elementary Kebumen has run well, although not $100 \%$, this is very good for the implementation of inclusive education. It can be conducted in a general school, but in one condition, schools become inclusive schools must have a policy of inclusive education, as a guideline in conducting the study.

Most of all of the policies of school in Kebumen are gotten from some resources, such as professional organizations, advocacy community and social organizations. Some of the support resources are not from schools, but professional organizations, advocacy community and social organizations.

Some aspects influence the school policy in the implementation of inclusive education, namely changing school policy in terms of costs, good relationships with the other schools so that to create positive changes in inclusive education and mechanisms for supporting inclusive education. It can be drawn that most of the schools have the above policy aspects. This issue can be happenned because of the difficulty of changing school policies because of cost and due to give limitations which may affect teaching and learning in schools.

2. School environment to support the inclusive education system

In creating an inclusive environment, it is necessary to adapt the environment with learning-friendly adjustment. For special education, the environment is very necessary to have adapt so that it is used-well for children with special needs. For instance, mobility for learners with visual impairments. The healthy neighborhood around the school as clean drinking water and a healthy diet is also a point that must be considered in the adaptation of an inclusive educational environment.
Based on the results of data analysis are showed that most of the elementary schools in Kebumen have facilities to fulfil the needs of diverse students. It is caused by a lack of funds from each school to complete and have no the facilities for students with special needs. As a result, children experience obstacles and cannot fully adapt to the environment and lacking in enthusiasm for learning. It is caused by a lack of effective registration of schools because the obstacles in developing inclusive education so that services the institution also do not reduce funding for the complete facility for children who are included.

However, viewing from the availability of healthy foods and beverages in the school environment, it is showed that almost all schools have clean drinking water and canteen that sells nutritious foods. This is because these schools have established the cooperation with local health agencies.

3. Skills, knowledge and attitudes of teachers regarding the implementation of an inclusive education system

A teacher must have skills in teaching. With his background and abilities that vary in inclusive schools, the teachers are required to have teaching skills. Teachers must be able to adjust the conditions of learning materials and students with disabilities in the classroom and be able to adapt the curriculum according to the needs of the students. Meanwhile, in terms of knowledge, regular teachers who teach students with disabilities must know and understand the disorder and disability-owned subsidiary.

Based on the result of data analysis, it shows that only a few teachers are able to teach and have the skills and knowledge of inclusive education. It is only a few teachers involve in the recruitment of school-aged children in the society. Besides, the number of teachers cannot use the right curriculum which must be appropriated with the needs of the students, especially the need of students with special needs. All of the teachers need to be recognized the curriculum regarding the factors of children in abnormalities.

The attitude of teachers to children in the regular school must be considered in the implementation of inclusive education. Master classes and special guidance counsellor have to open and accept every situation of children so that they do not feel insecure or isolated in the classroom or school environment.

The attitudes of teachers toward inclusive education show that almost all teachers in elementary Kebumen have a positive attitude toward the implementation of inclusive education and also the children. It can be seen 
from the many teachers who have high expectations of children and being open-hearted to the presence of children.

4. Competence of teachers in implementing inclusive education system

Competence is a set of knowledge and skills that must be owned by a person in performing their duties. Knowledge and these skills can be obtained from pre-primary education or training positions. From the results of data analysis are showed that the competence of the teachers who teach in inclusive elementary in Kebumen is not completely worked up. Most of the teachers from all of the inclusive elementary in Kebumen have a high competence in inclusive education. The teacher who has attended a workshop in inclusive education carries out communication to parents related to inclusive education and is able to develop teaching materials. Mostly, teachers who are competent in the description above, due to the inequality in training and workshops organized in inclusive education, then not all teachers can attend the training. In addition, the training is held only for a special mentor or teachers in regular schools. Even though the school send continuously specifical tutor training, they do not optimally determine the characteristics of inclusive education.

\section{Conditions of studentss in schools}

Goals of inclusive education are all schoolaged children, including children with special needs, have the equal education. ABK consists of children experiencing a permanent disability or retardation, and temporary or obstacles in their development mind. In addition, children with special needs or children who live in remote areas or underdeveloped, tribal, victims of natural disasters or social, poverty, color, gender, race, language, culture, religion, place of residence, political groups, twins, orphans, orphans strays, child rural, city boy, abandoned children, homeless, children discarded, children involved in the system of juvenile courts, children exposed areas of armed conflict, child beggars, children affected by drug HIV / AIDS (PLWHA), homeless children and nomads are targeted in an inclusive education.

From the analysis of the data is showed that almost all of the teachers receive all the students who attend schools in the inclusions. Teachers should have open-hearted to all children, full of pay attention to all children without differentiate the backgrounds and abilities of all children.

Moreover, the school that provides opportunities for all students in making class rules in inclusive schools, is found in almost the half of the teachers who provide such opportunities to the students.
6. The contents of the curriculum in schools

The curriculum is a device of subjects and programs of education. It is provided by an institution of education providers that contains lesson plans that will be given to participants as a lesson in one period of education.

From the analysis of the data, it shows that the teachers who teach in inclusive elementary in Kebumen use a curriculum that is adapted to the conditions of each student. It can be seen from almost all teachers use teaching methods that differ to suit the needs and abilities of children. The material that is taught such as load images, examples and information about various things and virtually all of the inclusive elementary teachers in Kebumen adapt the curriculum for the children with disabilities.

However, many teachers use the environments and available natural resources (easier and cheaper) to assist students in learning and using the curriculum. Thus, it promotes attitudes such as respect, tolerance and knowledge about the background and the diversity of culture.

7. Assessment in school

Arikunto (2003) states that evaluation is a series of activities that aims to measure the success of educational programs. The assessment for children with special needs is not the same as a normal child in general. It is adjusted to the ability of the children with special needs.

From the analysis of the data shows that the assessment in the inclusive elementary schools in Kebumen use instruments that is suitable for the conditions of students. It can be seen that almost all of the teachers provide remedial teaching for the students and have a suitable instrument for the evaluation in giving a score test.

8. Supports from the society regarding the existence of inclusive schools

The implementation of inclusive education is not only the responsibility of government, but also the other education stakeholders, such as the society must be involved in order to promote education. Moreover, in the spirit of regional autonomy, education is also one of the decentralized fields. Thus, the involvement of the society is needed as well.

Based on the results of data analysis, shows that some people such as parents are willing to assist and support the implementation of inclusive education. This is due to the lack of knowledge and their understanding of the education system so as some people and parents 
are not interested to participate in the implementation of inclusive education in schools. It is better for teachers and other school parties to socialize the inclusive education. By doing so, both the community in a society and the parents are able to contribute together.

Based on the existing components on a questionnaire, the result of a common data format is 11.6 with 19 ideal standard data for inclusion schoolspecific data. Then, based on a questionnaire analysis is obtained from 104.2 to 138 . While the ideal value standard for implementing an evaluation analysis of inclusive schools is acquired 159, first with a total score of 381. Thus, the general evaluation of the implementation of inclusive schools in Kebumen achieves an average $60 \%$ in the medium category. This result implies that the implementation of inclusion schools in the regency of Kebumen needs to be optimized in terms of institution, curriculum, learning, appraisal, student affairs, human resources, facilities and infrastructure, financing and society's participation.

\section{CONCLUSION}

1. Implementation of primary school inclusion in Kebumen generally can be accomplished even in the medium category.

2. Educational inclusion is an education which services for children with special needs, regardless of their physical, intellectual, social, emotional, and other conditions are retarded. They study together with normal children in regular schools.

3. Evaluation of the implementation of the inclusion of primary schools in Kebumen is a challenge as

[10] Openshaw, Linda. 2008. Social Work In School. New York : The Guildford Press

[11] Suharsimi Arikunto. 2005. Manajemen Penelitian. Jakarta : PT Aprimary school Mahasatya.

[12] Sumadi Suryabrata. 2000. Metodologi Penelitian. Jakarta : PT Raja Grafindo Persada.

[13] Suparno, Edi Purwanto. Tanpa Tahun. Pendidikan Akan Kebutuhan Khusus Unit 2

[14] Stainback, Susan \&Stainback, William. (1996). Inclusion, A Guide for Educators. London, Toronto, Sydney : Paul. H. Brokes Publishing, Co. Baltimore,

[15] Stubbs, Sue. 2002. Inclusive Education Where There Are Resources : The Atlas Alliance

[16] Tarmansyah. 2007. Inklusi (Pendidikan Untuk Semua). Jakarta :Depdiknas.

[17] Tarmansyah. 2012. Pedoman Pengembangan Pendidikan Karakter di Sekolah Inklusif. Padang : Direktorat Pembinaan Pendidikan Layanan Khusus. one of the alternatives in the implementation of inclusive schools. Thus, it is expected that the provision of inclusive elementary school is able to complete the training and understanding of the knowledge, and have a commitment for the teachers to support and raise the awareness in developing inclusive school

\section{REFERENCES}

[1] Andrews, Amanda Ajodhia\& Frankel, Elaine. (2010). Inclusive Education in Guyana : A Call For Change. International Journal of Special Education. 25 (1).

[2] Bandi Delphie. 2006. Pembelajaran Anak Berkebutuhan Khusus. Bandung : Refika Aditama.

[3] Budhi Wibhawa, Santoso T. Raharjo, Meilany Budiarti S. 2010. Dasar-Dasar Pekerjaan Sosial, Bandung : Widya Padjadjaran.

[4] Davies Brent, Ellison Linda, (1998) "Futures and strategic perspectives in school planning", International Journal of Educational Management, Vol. 12 Issue : 3, pp. 133-140, https://doi.org/10.1108/09513549810209130

[5] Jurnal Ilmiah Pendidikan Khusus. "Proses Pembelajaran Dalam Setting Inklusi Di Sekolah Dasar. Vol. 1, No. 1, Januari 2012

[6] Jurnal Pendidikan Khusus. Fenomena Penyelenggaraan Pendidikan Inklusi Bagi Anak Berkebutuhan Khusus. Vol. 7, No. 2, November 2010

[7] Lunenburg, 2010, "School Fasilities Management", National Forum of Educational Administration \& Supervision Journal. 27(4). 1-7.

[8] Mdikana, Andile., Ntshangase, Sibusiso \&Mayekiso, Tokozile. (2009). International Journal of Specil Education. 22(1)

[9] Mega Iswari. 2007. Kecakapan Hidup Bagi Anak Berkebutuhan Khusus. Jakarta :Depdiknas 